\title{
HISTOCHEMICAL DEMONSTRATION OF MONOAMINES IN THE THYMUS OF RATS
}

\author{
MOTOHATSU FUJIWARA, TAKASHI MURYOBAYASHI \\ AND KIRO SHIMAMOTO \\ Department of Pharmacology, Faculty of Medicine, Kyoto University, Sakyo-ku, Kyoto
}

Received for publication September 3, 1966

With use of highly sensitive and specific fluorescence method for demonstrating monoamines at the cellular level (1), we have started experiments to elucidate the existence of monoamines in the thymus of mammals. Pieces of thymus of adult female Wistar rats $(150-200 \mathrm{~g})$ were freeze-dried, treated with paraformaldehyde, embedded in paraffin, sectioned and mounted for fluorescence microscopy, as described previously (2).

The monoamine-storing structures were seen in the thymus of rats : 1 ) adrenergic fibers, which show intense, greenish catecholamine fluorescence, and 2) yellowish fluorescent 5-hydroxytryptamine (5-HT)- containing cells which on the basis of their metachromasia by toluidine blue staining should be identified as mast cells. Most of adrenergic fibers were those which innervated small arteries

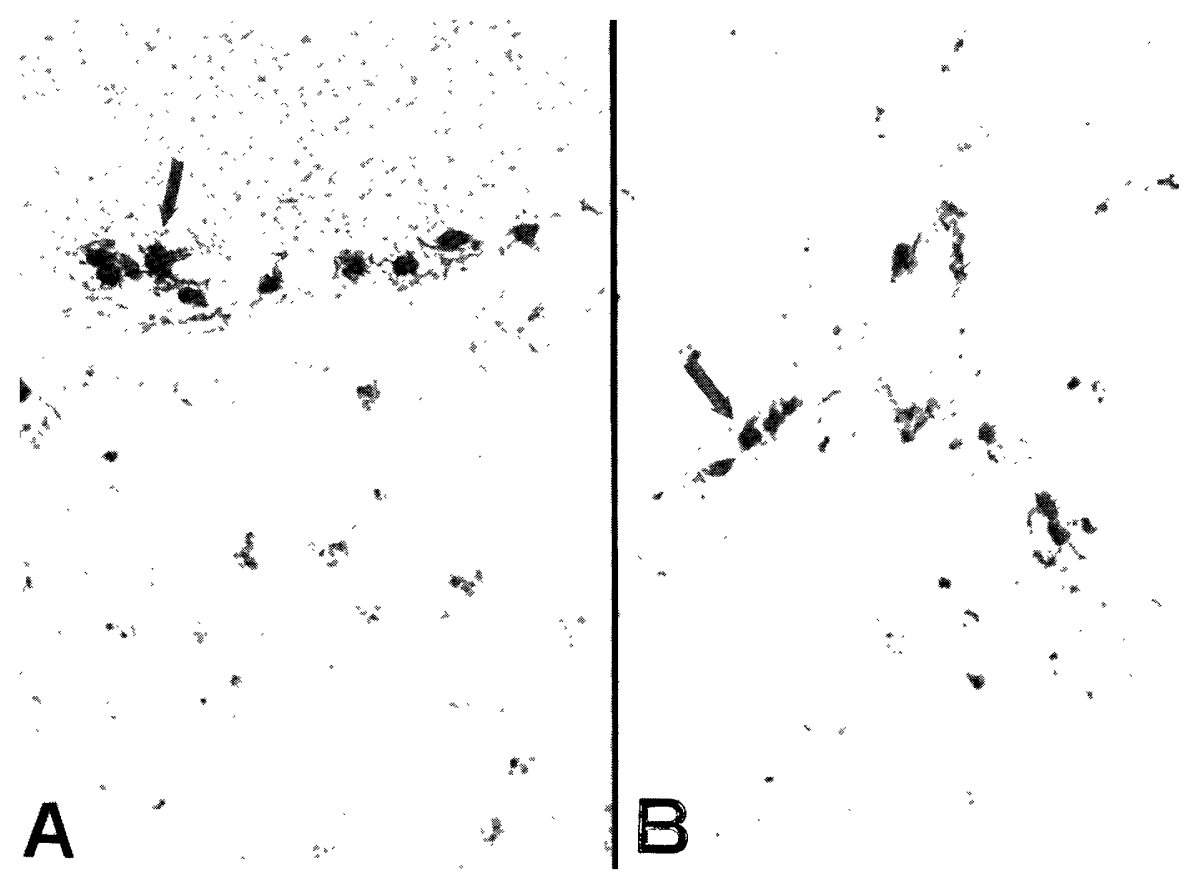

Fig. 1. Thymus of normal rat. A : Strongly fluorescent mast cells $(\uparrow)$ can be seen in the capsular connective tissue. B : Yellowish fluorescent mast cells $(\uparrow)$, and greenish fluorescent adrenergic fibers around small arteries are seen in the interlobular septa. Nonspecific autofluorescence in the lobules. Magnifications : $\times 128$. 
running in the interlobular connective tissues. The 5-HT- containing mast cells were exclusively present in the connective tissues of capsule and interlobular septa (Fig. 1 A \& B). Some of them were located in the vicinity of arterioles. Within the lobules of thymus tissue there were several autofluorescent materials, but these were easily distinguishable from specific 5-HT fluorescence. Neither 5-HT nor catecholamine fluorescence was obtained in the cortex or medulla of lobules even after the administration of dopa or 5-hydroxytryptophan. Thus, the presence of thymic 5-HT was confined to mast cells, the localization of which showed a good agreement with those reported by other investigators (3-6). However, there exist considerable species variations regarding the monoamine content of mast cells in different skin areas (7-10). It is of interest that 5-HT of mast cells is strategically located outside the thymus tissue proper to affect a blood-thymus barrier mechanism. Experiments are in progress on thymus of other mammalian species.

We gratefully acknowledge the valuable discussions with Dr. M. Kotani of Department of Anatomy.

\section{REFERENCES}

1) Falck, B. : Acta physiol. scand. 56, Suppl. 197 (1962) ; 2) Fujiwara, M., TanakÁ, C., Hikosaka, H. and Okegawa, T.: J. Histochem. Cytochem. 14, 483 (1966) ; 3) Weill, P. : Arch. mikros. Anat. 83, 305 (1913) ; 4) Baker, B.L., INGLe, D.J. And Li, C.H. : Amer. J. Anat. 88, 313 (1951) ; 5) KátZberg, A.A. : Anat. Rec. 118, 393 (1954) ; 6) Klug, H. : Acta biol. med. germanica 6, 545 (1961) ; 7) Bhattacharya, B.K. and Lewis, G.P. : Brit. J. Pharmacol. 11, 202 (1956) ; 8) Parratt, J.R. and West, G.B. : J. Physiol. 137, 169 (1957) ; 9) Adams-Ray, J., Dahlström, A., Fuxe, K. and Hullarp, N.-Å. : Experientia 20, 80 (1964) ; 10) FujII, A. And Imamura, S. : Unpublished observations. 